\title{
MODERN ASPECTS IN DIAGNOSIS OF TONGUE`S PARAFUNCTIONS (LITERATURE REWIEV)
}

10.36740/WLek202012123

\author{
Lyubov V. Smaglyuk, Maryna V. Trofymenko, Alevtyna M. Bilous \\ UKRAINIAN MEDICAL STOMATOLOGICAL ACADEMY, POLTAVA, UKRAINE
}

\begin{abstract}
The aim: To analyze modern research methods that allow to determine the features of the position of the tongue during the functions of swallowing and speech. Materials and methods: An analysis of 37 literature sources, which contains information about the methods of examination of patients with dento-maxillar anomalies. Conclusions: The functions of the tongue (swallowing and speaking) are very complex and coordinated movements that require the activation of many anatomical structures. Therefore, the disorders of the tongue during swallowing and speech are still considered by scientists as the most difficult in terms of correction and achieving of the long-term and stable results of orthodontic treatment. The study of modern trends in the diagnosis of the state of language functions in terms of understanding the functioning of the dental-maxillary area as a masticatory organ, the work and condition of the components of which depend on many systems of the human body, is relevant.

Thus, the emergence of new and modifications of existing research methods undoubtedly expand the capabilities of modern orthodontists. However, this does not reduce the importance of the clinical stage of examination of patients with disorders of the maxillofacial area, including the functions of the tongue. Therefore, it is necessary to know and understand the advantages and disadvantages of modern and existing research technologies, which will allow to choose a communicatively integrated and differentiated approach to diagnostic issues in each clinical case.
\end{abstract}

KEY WORDS: dental-jaw area, swallowing, speech, postural balance, hyoid bone

Wiad Lek. 2020;73(12 p. I):2683-2687

\section{INTRODUCTION}

Orthodontists and scientists around the world do not stop discussions on etiopathogenesis, diagnosis and treatment of dental anomalies and deformations, taking into account the individual approach to achieving morpho-functional and aesthetic harmony of the entire maxillofacial area $[1,2,3]$. But in the modern scientific literature, the most discussed are those related to the concept that considersdental-maxillary area (DMA) as a part of a all-in-one stomatognathic system $[4,5,6,7]$. Certain anatomical and functional features and neuro-muscular connections of the dental-maxillary area are important components for maintaining of postural balance. The concept of postural balance (system of regulation of the vertical posture of the human body), as a set of parameters and reflex feedback, tuned according to the "instructions" of the vestibular apparatus, visual system, joint and muscle receptors was formulated by Nashner L. M. [8]. Given the fact that the DMA is an integral part of the human musculoskeletal system, orofacial dysfunctions are considered in the context of relationship of cause and effect in addressing issues of achieving postural balance.

The tongue, as one of the elements of DMA, is a massive muscular organ. It is important for: chewing, swallowing, speech, breathing (ensuring the width of the airways), posture, socialization. The correct spatial orientation of the tongue in the oral cavity during the process of the swallowing, speech, and in physiological rest is one of the components for maintaining of postural balance [3, 4]. It should be added, that an important role in maintaining the vertical natural position of man and, at the same time, an indicator of the position and function of the tongue, is the position of the hyoid bone relative to the base of the skull and lower jaw. The functions of the tongue (swallowing and speaking) are very elaborated and coordinated movements that require the activation of many anatomical structures. Insufficient functional stimulation of stomatognathic system, especially speech functions, may be a major factor in maintaining a child's swallowing pattern. The hyoid bone is an important bone structure in this process. Some authors emphasize that it is also called the "lingual bone".

All clinicians and scientists recognize the morphogenetic role of tongue and the fact that any change in the spatial relationship between the hyoid bone and the tongue has a broad functional significance and mutual consequences. Parafunctions of the tongue are still considered by scientists as the most difficult in aspects of correction and achieving long-term and stable results of orthodontic treatment.

It is important to study current trends in diagnosis of the state of the functions of the tongue not only at the local level of the dental-maxillary area, but in its understanding as a masticatory organ, the work and condition of the components of which depend on many systems of the human body. 


\section{THE AIM}

To analyze modern research methods that allow to determine the features of the position of the tongue during the functions of swallowing and speech.

\section{MATERIALS AND METHODS}

An analysis of 37 literature sources, which contains information about the methods of examination of patients with dento-maxillar anomalies, which are accompanied by impaired position of the tongue during swallowing and speech was conducted.

\section{REVIEW AND DISCUSSION}

The development of modern technologies and the continuous integration of digital research methods into the processes of diagnostic and treatment, most of the criteria needed to objectify the picture of the disease and treatment planning. The success of orthodontic treatment to some extent depends on the quality of diagnosis, which must be systematized through the use of certain algorithms. Thus, on the basis of research and analysis of literature data, we have developed an "Algorithm for studying of the state and position of the tongue during the swallowing and speech functions", which included static and dynamic research [3] (2016). Dynamic examination of the state of the functions of the tongue includes a number of paraclinical techniques, including the author's "Method for determining of the position of the tongue during swallowing and speech" [4, 5] (2008). This method allows us clearly visualize for the dynamics of orthodontic correction of the incorrect position of the tongue during swallowing and speech without the use of high-value technologies by analyzing of the contour-scheme diagrams of the obtained photopalatograms of a series of diagnostic caps.Ladan Eslamian, Amir Peyman Leilazpour (2006) [5] tried to objectify the results of pronunciation control of certain consonant sounds and separate words in patients with anterior tongue during swallowing by making a removable maxillary apparatus with 12 electrodes, each of which was connected to special electropalatovisual devices.

Thus, research in bottom decades has demonstrateof a tendency to enlargement of aspects of paraclinical study of the state of tongue's functions. The method of cephalometric analysis is one of the most common and available. Using of this method makes it easy to study the features of craniofacial morphology in patients with violation of tongue's functions, to determine the spatial relationship between the skull, vertebrae, mandible and hyoid bone $[9,10,11]$. In the modern context of diagnostic of the state of tongue's functions, this technique is mainly used to determine the parameters of the tongue, supralingual and sublingual space, the state of the pharyngeal airways, the position of the sublingual bone and the tongue at rest. Malkoc S., Usumez S., Nur M., Donaghyd C.E. et al. (2005) [12] after studying the position of the tongue and sublingual bone, showed that the measurements of these parameters are very well reflected on the lateral cephalograms with the natural position of the head. Malkoc S., Usumez S., Nur M., Donaghyd C.E., et al. (2005) [12] after studying the position of the tongue and sublingual bone, showed that the measurements of these parameters are very well reflected on the lateral cephalograms with the natural position of the head. In their studies, Sheng C.M., Linb L.H., Suc Y., Tsaid H.H. (2009) [13] proved that it is important to take into account sexual dimorphism and age of a patient. They determined that with age there are changes in the development of the depth of the pharyngeal airways and the position of the hyoid bone. Sexual dimorphism affects the condition of the lower respiratory tract of the pharynx and the direction of change of the sublingual bones in the vertical position. The results, according to the authors opinion, may provide an answer to the reason why some respiratory disorders predominate in men. The hyoid bone, as an anatomical structure, to which most muscles involved in swallowing are attached, may change its position in the case of atypical swallowing $[14,15]$. According to the authors, the radiographic position of the hyoid bone can provide useful information that helps in the diagnosis of atypical swallowing in children.

According to computed tomography, the position of the tongue and hyoid bone affects the condition of the airways. It is important to evaluate these parameters in subjects with normal nasal breathing, but with different values of ANB angle in class I and II. The authors determined that the ANB angle is a significant predictor for class I and II diagnoses. Mean pharyngeal and hyoid bone values were lower in patients with class II. Mean tongue parameters generally did not differ between classes I and II, except for the position of the tongue (TT-LOP), which was higher in patients with class II subclass 1 . In general, the authors did not identify differences in anteroposterior measurements of the pharyngeal airways, the position and relationship of the hyoid bone and tongue. between patients with I and II classes. The anterior-posterior size of the upper respiratory tract is usually supported by the adaptation of the tongue and hyoid bone. The result should be considered in the sense that only anteroposterior measurements were taken into account. The vertical and transverse sizes of these tricky anatomical formations should be investigated on the basis of three-dimensional (3-D) imaging techniques to determine the correlation between them.

Studies by Shigeta Y., Ogawa T., Ando E., Clark G.T. and Enciso R. (2011) [16] were devoted to the effect on the upper respiratory tract of the ratio of the size of the tongue and lower jaw in male patients with obstructive sleep apnea. The average volume of the tongue and lower jaw was found to be 79,00 $\pm 1,06 \mathrm{~cm}$ and 87,80 $\pm 1,21 \mathrm{~cm}$, respectively. The authors have shown that an increase in body mass index lead for increasing of the volume of the tongue, which may be one of the causes of sleep apnea. The volume of the tongue affects the low oxygen saturation, and not on the index of apnea-hypopnea in obstructive sleep apnea [17]. The authors noted that the modified Mallampati score (Mallampati score - a method for predicting of 
compound intubation based on imaging in patients with soft palate, pharynx, tonsils, and tongue) would be a useful physical examination to predict tongue size.

According to Fabrice Liégeois, Adelin Albert and Michel Limme (2010) [18] MRI is a more accurate and reliable method of determining the volume of the tongue. Virtual computerized reconstructions greatly facilitate this process. However, this technique is too expensive and not suitable for daily orthodontic practice. The results of this study show that not only is the size of the tongue closely related to demographic and biometric characteristics, but there is also a significant correlation between the volume of the tongue and the area of the lingual shadow measured on the lateral cephalograms. Thus, the volume of the tongue can be accurately estimated by using of the classic lateral radiographs of the skull, which are used in everyday practice. However, in some cases, the exact value may require an MRI evaluation.

To study the difference in tongue movements during infantile and somatic swallowing, the literature describes the use of ultrasound techniques [19]. The authors recorded the movements of the tip of the tongue and of the submental muscles on a videotape and then evaluated of it by using of a personal computer. The results of their research showed that the dorsal surface of the tongue, which was considered as an ideal for monitoring of its functions, is not suitable for determining of the type of swallowing. Conversely, m.genioglossus movements were found to be significantly various in different types of swallowing. Maja Ovsenik, Jure Volk and Maja Mušič Marolt (2014) [20] gave estimates of the nature of swallowing and the function of the tongue in this process by using of $2 \mathrm{D}$ ultrasonographic techniques with applying of B- and M-modes. They examined the swallowing pattern by the action of m.genioglossus on ultrasound images with a scanning line of an ultrasound transducer mounted on the tip of the tongue. Basic tongue movements (duration, range and speed)the authors compared in each subphase of swallowing in two groups of children of the period of temporary occlusion with the existing lateral cross-occlusion and without it. Using 3D ultrasound, Volk J, Kadivec M, Mušič M M and Ovsenik M (2010) [20] obtained and reconstructed in three adult patients reference three-dimensional ultrasound images of the tongue at different positions. These $3 \mathrm{D}$ models of the tongue were used in the following stages to study the position of the tongue in children with unilateral cross-bite and in comparison with children with normal occlusion during the period of temporary occlusion. Thus, according to this analysis, the difference in the position of the tongue in the norm and in the area of the bottom of the oral cavity was statistically significant, and this, according to the author's opinion, can be an important part of functional diagnosis before, during and after orthodontic treatment.

In the process of evolution, the development of speech function has caused a powerful impetus to the development of the stomatognathic system. Orofacial dysfunction is common situation in the orthodontic practice. But this is especially true of lip and tongue dysfunctions (Stahl F. et al.,
2007) [21]. The tongue is the main organ of articulation. But the literature has limited data on the description of the exact movements of some anatomical components of the speech process, including the lips and tongue, especially on their interaction during the formation of certain sound phonemes.

Koos et al. (2009) [11] has opinion, that the electromagnetic articulography (EMA) is the most appropriate technique for analyzing of these movements. According to the authors, this technique is the only one able to record the movements of the tongue and lips in time and space. In their studies, the authors compared the pronunciation sequences of CVC (consonant-vowel-consonant) and VCV (vowel-consonant-vowel), which were noted as reliable for achieving the goal of diagnosis. In their studies, Mehnert et al. (2009) [37] compared the results of MRI-analysis with the data of speech therapy to assess the functions of the tongue.

The following methods are also known for studying the state of tongue functions: video analysis, optoelectric systems, methods of measuring lip and tongue pressure, use of strain gauges, radiographic microbeam technology, etc.

But, taking into account the fact that normally more than 20 muscles of the maxillofacial and sublingual area and pharynx take part in the act of swallowing and speech, classical methods associated with the study of various criteria of muscle activity during these functions in normal and in pathology do not leave their positions in the diagnosis. Thus, Heleen Lambrechts, Evelyne De Baets, Steffen Fieuws and Guy Willems (2010) [22], by using Myometer 160 , conduct a study of lip and tongue muscle pressure by cross-examining of 107 patients aged 7-45 years who sought orthodontic care. They determined a statistically significant difference in lip muscle pressure for men and women, as well as depending on the Angle class and the different bad habits. The pressure of the lip muscle does not significantly correlate with age and occlusal characteristics. Also, no evidence was found between tongue pressure and any of these criteria.

In the process of finding objective diagnostic criteria for the state of the functions of the tongue on the basis of determining the activity of the muscles of the maxillofacial area, the method of electromyography acquires new relevance $[23,24,25,26,27,28,29]$. A number of studies in recent decades have shown the feasibility of using this method at all stages of work with orthodontic patients, especially in the case of existing functional disorders of the maxillofacial area, including in combination with posturological problems. In the presence of incorrect swallowing, the waves of contraction begin with the muscles of the face, and the anterior position of the tongue causes an additional contraction of $\mathrm{mm}$. palatoglossus, palatostyloglossus, mylohyoideus, and sometimes of the neck muscles, which can cause anteflexion of the muscles of the neck and head. There is a stretching of a neck forward that facilitates insertion of a food lump on tongue and its advancement in a throat. L.V. Smaglyuk, V.I. Smaglyuk, A.V. Liakhovska, M.V. Trofymenko (2020) $[6,30,31,32,33]$ in their study proved the involvement of the muscles of the face and neck to a process of teeth clench, movements of a lower jaw, swallowing. It was found 
that the EMG activity $\mathrm{m}$. orbicularis oris during maximal compression of the teeth, displacement of the mandible forward (protrusion) and swallowing correlates with the EMG-activity of the sternocleidomastoid muscles. In our opinion, the obtained data indicate the functional unity of the neuromuscular component of the stomatognathic system and the need to study the bioelectrical activity of these muscles in subjects with functional disorders, especially related to the movements of the lower jaw and tongue.

\section{CONCLUSIONS}

Thus, the emergence of new and modifications of existing research methods undoubtedly expand the capabilities of modern orthodontists. However, this does not reduce the importance of the clinical stage of examination of patients with disorders of the maxillofacial area, including the functions of the tongue. Therefore, it is necessary to know and understand the advantages and disadvantages of modern and existing research technologies, which will allow to choose a communicatively integrated and differentiated approach to diagnostic issues in each clinical case.

\section{REFERENCES}

1. Smaglyuk L.V., Trofimenko M.V. Narusheniya funktsiy chelyustnolitsevoy oblasti kak vedushchiy etiologicheskiy faktor formirovaniya zubochelyustnykh anomaliy v pervyy period smennogo prikusa. [Dysfunctions of the maxillofacial region as a leading etiological factor in the formation of dentoalveolar anomalies in the first period of a replaceable bite]. Ortodontiya. 2007; 3 (39): 79. (in Russian).

2. Smaglyuk L.V., Belous A.N. Planirovanie ob'ema i srokov ortodonticheskogo lecheniya patsientov s transverzalnyimi anomaliyami prikusa. [Planning of volume and terms of orthodontic treatment of patients with transversal malocclusion]. Wiad Lek, 2016; LXIX, 2 (II): 258-261. (in Russian).

3. Smaglyuk L.V., Trofimenko M.V., Karasiunok A.Ye. et al. Alhorytm vyvchennya stanu ta polozhennya yazyka pid chas funktsiy kovtannya ta movlennya [Algorithm for studying the state and position of the tongue during swallowing and speech functions]. Naukovo-praktychna konferentsiya z mizhnarodnoyu uchastyu «Ukrayins'ka ortodontychna shkola: vchora, s'ohodni, zavtra» prysvyachenoyi 80-richchyu z dnya narodzhennya profesora Svitlany Ivanivny Doroshenko: materialy konferentsiyi, 2016; 53-56. (in Ukrainian)

4. Trofimenko M.V. Vyznachennya pozytsiyi yazyka pid chas funktsiy kovtannya ta movlennya v protsesi ortodontychnoho likuvannya. Aktual'ni problemy suchasnoyi medytsyny. [Determining the position of the tongue during the functions of swallowing and speech in the process of orthodontic treatment. Actual problems of modern medicine].Visnyk ukrayins'koyi medychnoyi stomatolohichnoyi akademiyi, 2008;4 (24): 72-73. (in Ukrainian).

5. Smaglyuk L.V., Trofimenko M.V. Sposib vyznachennya polozhennya yazyka pid chas kovtannya ta movlennya. [A method of determining the position of the tongue when swallowing and speaking]. Visnyk stomatolohiyi, 2008; 2 (62): 102-104. (in Ukrainian)

6. Smaglyuk L.V., Smaglyuk V.I., Liakhovska A.V., Trofymenko M.V. EMGactivity of muscles of the cranio-mandibular system during functions of the dento-facial region. The world of medicine and biology. 2020; 1 (71): 128-131.
7. Lyakhova N.0., Bilous A.M., Nesterenko 0.M. Medyko-sotsial'ni ta orhanizatsiyno-pravovi pytannya orhanizatsitni nadannya ortodontychnoyi dopomohy dytyachomu naselennyu Ukrayiny v period reformuvannya haluzi okhorony zdorov'ya. [Medico-social, organizational and legal issues of organizing the provision of orthodontic care to the children's population of Ukreine during the reform of the health care sector]. Visnyk problem biolohiyi i medytsyny, 2014; 3 (110): 213-216.

8. Nashner L.M., Towe A.L., Luschel E.S. Analysis of stance posture in humans. In: Handbook of Behavioral Neurobiology. Motor Coordination. Eds.: New York: Plenum Press, 1981; 5: 527-565.

9. Eslamian L., Leilazpour A.P. Tongue to palate contact during speech in subjects with and without a tongue thrust. European Journal of Orthodontics. 2006; 28 (5): 475-479.

10. SmaglyukL.,Voronkova A., Karasiunok A., Liakhovska A. Interdisciplinary approach to diagnostics of malocclusion (review). Wiadomosci Lekarsrie, 2019; 72 (5): 918-922.

11. Koos B., Horn H., Schaupp E., Axmann D. Lip and tongue movements during phonetic sequences: analysis and definition of normal values. European Journal of Orthodontics, 2013; 35 (1):51-58.

12. Malkoc S., Usumez S., Nur M., Donaghyd C.E. Reproducibility of airway dimensions and tongue and hyoid positions on lateral cephalograms. American Journal of Orthodontics and Dentofacial Orthopedics, 2005;128:513-516.

13. Sheng C.M., Linb L.H., Suc Y., Tsaid H.H. Developmental changes in pharyngeal airway depth and hyoid bone position from childhood to young adulthood. Angle Orthodontist, 2009; 79(3): 484-490.

14. Bertolini M.M., Vilhegas S., Paschoal J.R. Cephalometric evaluation in children presenting adapted swallowing during mixed dentition International Journal of Orofacial Myology. 2003; 29: 29-41.

15. Ferraz M.J., Nouer D.F., Teixeira J.R. Cephalometric assessment of the hyoid bone position in oral breathing children. Brazilian Journal of Otorrynolaryngology, 2007; 73: 47-52.

16. Shigeta Y., Ogawa T., Ando E., Clark G.T. Influence of tongue/mandible volume ratio on oropharyngeal airway in Japanese male patients with obstructive sleep apnea. Oral Surgery, Oral Medicine, Oral Pathology, Oral Radiology, and Endodontics, 2011; 111(2): 239-243.

17. Ahn S.H., Kim J., Min H.J., Chung H.J. et al. Tongue Volume Influences Lowest Oxygen Saturation but Not Apnea-Hypopnea Index in Obstructive Sleep Apnea. 2015; 10(8): 0135796.

18. Liégeois F., Albert A., Limme M.. Comparison between tongue volume from magnetic resonance images and tongue area from profile cephalograms. European Journal of Orthodontics, 2010; 32 (4): 381-386.

19. Peng C.L., Jost-Brinkmann P.G., Yoshida N., Miethke R.R. et al. Differential diagnosis between infantile and mature swallowing with ultrasonography. European Journal of Orthodontics, 2003; 25 (5): 451- 456.

20. Ovsenik M., Volk J., Marolt M.M. 2D ultrasound evaluation of swallowing in children with unilateral posterior crossbite. European Journal of Orthodontics. 2014; 36 (6): 665-671.

21. Stahl F., Grabowski R., Gaebel M., Kundt G. Relationship between occlusal findings and orofacial myofunctional status in primary and mixed dentition. Part II: Prevalence of Orofacial Dysfunctions J Orofac Orthop. 2007; 68 (2): 74-90.

22. Lambrechts $H_{\text {., }}$ De Baets E., Fieuws S. Lip and tongue pressure in orthodontic patients. European Journal of Orthodontics. 2010; 32 (4): 466 . 
23. Santos T., Faria C., Regalo S.CH., Thomazinho A. et al. Masticatory muscle activity in children with a skeletal or dentoalveolar open bite. European Journal of Orthodontics. 2010; 32 (4): 453-458.

24. Gamboa N.A., Miralles R., Valenzuela S. Comparison of muscle activity between subjects with or without lip competence: Electromyographic activity of lips, supra- and infrahyoid muscles. Cranio. 2017; 35(6): 385-391.

25. Murakami K., Hirano H., Watanabe Y., Edahiro A. et al. Relationship between swallowing function and the skeletal muscle mass of older adults requiring long-term care. Geriatr Gerontol Int. 2015; 15(10): $1185-1192$.

26. Poorjavad M., Talebian S., Ansari N.N., Soleymani Z. Surface electromyographic assessment of swallowing function. Iran J Med Sci. 2017; 42(2): 194-200.

27. Stepp C.E. Surface electromyography for speech and swallowing systems: measurement, analysis, and interpretation. J Speech Lang Hear Res. 2012; 55(4): 1232-1246.

28. Tartaglia G.M., Lodetti G., Paiva G., De Felicio C.M. et al. Surface electromyographic assessment of patients with long lasting temporomandibular joint disorder pain. J Electromyogr Kinesiol, 2011; 21(4): 659-64.

29. Zhu M., Yu B., Yang W., Jiang Y., Lu L., et al.. Evaluation of normal swallowing functions by using dynamic high-density surface electromyography maps. 2017; 16: 133.

30. Ahn S.H., Kim J., Min H.J., Chung H.J. Tongue Volume Influences Lowest Oxygen Saturation but Not Apnea-Hypopnea Index in Obstructive Sleep Apnea . PLoS One. 2015; 10(8): 0135796.

31. Poorjavad M., Talebian S., Ansari N.N., Soleymani Z. Surface electromyographic assessment of swallowing function. Iran J Med Sci. 2017; 42(2):194-200.

32. Mehnert J., Landau H., Mussler A., Reinicke J. Comparison Between Logopedic and MRI Findings in Evaluating Tongue Function J Orofac Orthop. 2009; 70(6): 455-67.
33. Murakami K., Hirano H., Watanabe Y., Edahiro A. et al. Relationship between swallowing function and the skeletal muscle mass of older adults requiring long-term care. Geriatr Gerontol Int. 2015; 15(10):1185-1192.

This article was performed as part of research work: "Interdisciplinary approach to the diagnosis and treatment of patients with dental anomalies and deformities"№ 0118 u004343

\section{ORCID and contributionship:}

Lyubov V. Smaglyuk: 0000-0002-7030-8313 A, E, F

Maryna V. Trofymenko: 0000-0002-7710-4241 ${ }^{B, C, D}$

Alevtyna M. Bilous: 0000-0002-7165-0516 ${ }^{B, C, D}$

\section{Conflict of interest:}

The Authors declare no conflict of interest

\section{CORRESPONDING AUTHOR}

Alevtyna M. Bilous

Ukrainian Medical Stomatological Academy

23 Shevchenko st., 36011 Poltava, Ukraine

tel: +380506147637

e-mail:alisa6sh8@gmail.com

Received: 03.04 .2020

Accepted: 28.09 .2020

A - Work concept and design, B - Data collection and analysis, C - Responsibility for statistical analysis,

D-Writing the article, $\mathbf{E}$-Critical review, $\mathbf{F}$ - Final approval of the article 